\title{
The natural rights of children
}

\author{
Walter E. Block ${ }^{1, \star}$, Ed Smith ${ }^{2}$, Jordan Reel ${ }^{3}$
}

\begin{abstract}
What does libertarian theory, Murray Rothbard's theory in particular, tell us about the rights of children? The two foundational principles of Rothbardian libertarianism are the sanctity of private property and the rule of non-aggression. Persons, including children, are "self-owners". Yet children, at a young age, are not yet capable of functioning fully as "self-owners." They must be cared for, and the caring will necessarily involve some degree of aggression in the form of supervision and restraint. Parents and other caregivers play the role of trustees; and just as the beneficiary of a trust has the right to petition a court to change trustees or terminate the trustee relationship, so a child, able to express his preferences when it comes to the nature and degree of supervision and restraint to which he will be subjected, should equally enjoy that right while, in terms of property rights, a biological caregiver may have better "title" than an adoptive caregiver to be the child's "trustee" given the child's inability to express a preference for one or the other. What may seem to a contemporary sensibility as an extreme degree of childhood independence in the choice of caregivers and other freedom from supervision and restraint was common in pre-industrial America and continues to be the rule in some native cultures.

Keywords: Children, Rights, Libertarianism, Babies Switched at Birth

Copyright: () 2014 by Kerman University of Medical Sciences

Citation: Block WE, Smith E, Reel J. The natural rights of children. Int J Health Policy Manag 2014; 2: 85-89.

doi: 10.15171/ijhpm.2014.20
\end{abstract}

\section{Introduction}

There are four sections in this paper. In section II we offer, and analyze, Rothbard's libertarian theory of children. Section III is our attempt to apply preference-based child rights theory. The burden of section IV is to offer a brief history of children's rights. In section $\mathrm{V}$, we mention and then respond to a series of objections that were articulated by the referee of this journal. Section VI concludes.

\section{Rothbard}

We analyze the natural rights of children from a libertarian perspective $(1,2)$. This philosophy is predicated upon two basic premises the Non-Aggression Principle (NAP), that no one may initiative force or the threat thereof against an innocent person and private property rights based on homesteading. The latter holds that he who first makes use of a resource enjoys the exclusive right to its use. Only through voluntary transfer can the right to use/exploit a resource be legitimately obtained. However, private property rights and the implication of the NAP are not so cut and dried when it comes to children. Here, some degree of aggression is unavoidable. And not only unavoidable, but also justified. Young children are unable to care for themselves. Caretakers must necessarily exercise a certain amount of "aggression" for the child's benefit: carrying, feeding, and nurturing the child without his consent. Under current law, when the child reaches the age of eighteen, the caregiver's authority terminates ${ }^{1}$.

Rothbard writes, "The right of self-ownership by each man has been established for adults, for natural self-owners who must use their minds to select and pursue their ends" (3).

Children are a challenge for all political philosophies, and

1. Different jurisdictions proscribe different ages, typically ranging from 14 to 21 , depending upon the issue involved. libertarianism constitutes no exception. The problem is that cognitive development occurs gradually (4). At each stage, the child acquires greater understanding of the world, but these steps usually occur at different rates; and some children may never fully develop their cognitive abilities. Not only do children develop cognitively at different rates, there are qualitative differences in their modes of cognitive development. Unfortunately, in today's world of clinically zealous psychiatrists, in tandem with the judicial system's readiness to acquiesce in questionable diagnoses, resulting standards could provide justification for nanny state like policies, and even various kinds of child abuse ${ }^{2}$. Mental disorders could be excessively invoked as grounds for curing/eliminating the rights of adults. Delayed cognitive development could provide zealous enforcers (psychiatrists, courts) with the justification to infringe illegitimately on a person's right to monitor/determine his own conduct, even for adults ${ }^{3}$.

2. There are some libertarians $(5,6)$ who make the argument that spanking is incompatible with the libertarian NAP. What do libertarians of this sort offer, instead, for child rearing? First and foremost, reasoning with the child. But, suppose he is too young, or too excited, for any such tactic to be fruitful? Then, second, there is the "time out": the child is confined to his room until he learns his lesson, and or has calmed down and has become amenable to reason. The difficulty here is that imposing a time out on a youngster, strictly speaking, is also a violation of the NAP. If one adult were to compel another to take a break along these lines he would be seen, clearly, to have engaged in kidnapping. That is exactly what a time out constitutes. Forcing someone against his will to calm down, or stand in the proverbial corner, or be confined to his bedroom is considered an assault (a threat); backing it up with physical violence would constitute a felony. Libertarian critics of spanking cannot be allowed to have it both ways, to have their cake and eat it too. If they want to treat children as full rights bearing persons, such that it would be a libertarian crime to violate the NAP against them, then they must adopt the same policies toward them as they would properly do for other adults: the threat or the initiation of violence would be strictly prohibited. No time outs either. 3. There is no one who has done more to combat this type of legislative and judicial over-reach than Thomas Ssasz. See on this $(7,8)$ 
Furthermore, recent advancements in developmental psychology have challenged the dominant view that infants/small children are mindless creatures. Indeed, as recently as a generation ago, most (many) psychologists, philosophers and psychiatrists were of the opinion that infants and young children were irrational, egocentric and amoral beings, unable to understand the workings of cause and effect, to empathize with the experiences of others or to appreciate the distinction between reality and fantasy. Many people continue to hold this view $(4)^{4}$.

Baillargeon, Spelke and Wasserman propose that infants have the ability to understand principles of physics and relations of cause and effect (9). Children may be less egocentric and better able to understand the world than many commentators previously gave them credit for. Gopnik and Repacholi contend that by the age of eighteen months, infants have acquired the ability to determine others' preferences based on facial expressions $(4,10)$. Recent advancements in child psychology suggest that youngsters are indeed able "to select and pursue their ends", thus making them homesteaders of their own bodies, legal adults, by the standard Rothbard (1998) sets out (3).

Rothbard's contributions to libertarian philosophy preceded much current research into early cognitive development. The time has come to update Rothbard's theory in light of this research.

Focusing on the caretaker, Rothbard writes that his right to make decisions on behalf of the child is not absolute:

"But surely the mother or parents may not receive the ownership of the child in absolute fee simple, because that would imply the bizarre state of affairs that a fifty-year old adult would be subject to the absolute and unquestioned jurisdiction of his seventyyear-old parent. So the parental property right must be limited in time. But it also must be limited in kind, for it surely would be grotesque for a libertarian who believes in the right of selfownership to advocate the right of a parent to murder or torture his or her children" (3).

It follows that parental ownership is not an absolute, but is of the nature of a guardianship relationship. In short, every baby from the moment of birth, possesses the right of self-ownership by virtue of his potential to become an adult. It would therefore be a violation of the child's rights if a parent or caretaker were to mutilate, torture, murder or subject a child to physical or emotional violence (3).

The relationship between the parent and child is not the only example of trustee rights in libertarian philosophy. The theory applies as well to those who may be unable to communicate their preferences (11). It is not disability that creates dependency. An individual may be temporarily disabled by, for example, falling under the influence of alcohol, opiates, marijuana, and other such substances that significantly reduce cognitive functioning yet hardly require legal supervision. A social drinker or recreational drug user may be so intoxicated that he may require the assistance of a caretaker, but so long as he is able to express his preferences, the appointment of a caretaker would violate his rights. The criterion upon which to base the need for a caretaker should not be mental disability, but an inability to express one's preferences.

Rothbard asserts that a child has attained the right to be selfgoverning (adult status) once he "leaves or 'runs away' from

4. Gopnik, a professor of psychology at the University of California, Berkeley, specializes in cognitive and language development. home ${ }^{5 "}$ (3). If we invoke the child's ability to express his preferences as a guide to the attainment of the full panoply of adult rights, disability, in itself, would be insufficient grounds to deny them.

Strictly speaking, an individual becomes self-governing at the moment of birth. When the infant reaches the toddler stage and begins to acquire facility with language, he becomes able verbally to express his preferences. At that point, a caretaker's rule may relax and continues to diminish as the child grows until, at age eighteen, legal emancipation begins and is rendered complete at age twenty-one. However, many individuals are qualified for partial or even complete emancipation prior to age eighteen let alone age twenty-one.

Full emancipation implies that a parent or guardian would lose all legal control of his child. However, in the free society, there would also be such a thing as partial emancipation. Here, the legal relationship takes on the nature of an implicit contract. The caretaker provides such essentials as food, education, healthcare and housing. In return, the child follows the caretaker's rules. The relationship between caretaker and child, in this respect, is akin to the relation between a diner and a restaurant at which the diner pays for his meal. If the child refuses to abide by the conditions dictated by his caregiver he has, as Rothbard states, " $[r]$ egardless of his age,... the absolute right to run away and to find new foster parents who will voluntarily adopt him, or to try to exist on his own" (3).

But this statement has to be interpreted sympathetically. Otherwise we arrive at the specter of a two year old throwing a tantrum and wanting to run away from home in a fit of pique, right then and there. Surely this cannot be the libertarian position. However, if we interpret Rothbard as saying that this can indeed be done, but not right then and there, not at a moment's notice, not without a by-your-leave from anyone apart from a baby in his "terrible twos", then the viewpoint makes more sense. This is not the beginning of the process, but rather the end of it: a court must pronounce judgment that this is indeed in the best interests of the tiny tot. Time must be used for sober analysis of the situation. Experts (social workers, psychologists) must be brought in to verify the facts of the case. Then and only then may this "absolute right to run away and to find new foster parents" be fully implemented. A two year old cannot just be allowed to wander off to be on his own because he resents the fact that he is not allowed to eat all the ice cream he wants-because his parents fear he will get a stomach ache. If these "runaway" rights of children are to be implemented in a reasonable way, judicial support must be acquired.

\section{Applying preference-based child rights}

We now have the means to examine more pointedly the ethical dilemmas involved in determining ${ }^{6}$ the respective rights of children and their caretakers. Consider the case of Rebecca Chittum and Callie Conley, switched at birth (12) at the University of Virginia Medical Center in 1995 (13). Some

\footnotetext{
5. In the spirit of Rothbardian terminology, we can say this occurs "when the child has homesteaded himself".

6. In a previous iteration of this paper, we wrote "balancing" instead of the word that now appears in the text, "determining". This change was purposeful and substantive. Libertarians do not "balance" rights. People either have rights, or they do not, and it is the function of the libertarian analyst to shed light on which is which. If there is a seeming conflict in rights, one or the other or both have been mis-specified.
} 
four years later, Paula Johnson, Callie's presumptive mother, discovered that the child she raised as her daughter, Callie, was born as Rebecca Chittum. Shortly thereafter, Rebecca's parents were killed in a car crash. Rebecca's grandparents became Callie's caregivers. Callie's biological mother unsuccessfully sued for custody while seeking to maintain custody of Rebecca (13). Let us reiterate, since it is important to be able to see precisely who is who in this case: Callie's biological mother, Paula Johnson, sued for custody of Callie who was being cared for by Rebecca's adoptive grandparents after Rebecca's adoptive parents were killed in a car crash. And Paula Johnson sought to keep custody of her adoptive daughter, Rebecca. Had Johnson prevailed in court, she would have been the mother of both babies.

The Rothbardian theory of children's rights helps us determine the just outcome though the result may seem curious. Rothbard poses two scenarios. The biological mother's right may prevail because she gave birth to the child. Or the presumptive parents' right may prevail because they initially raised the child.

Initially, the parents play the role of the child's trustee. The fact of biological parenthood defeats any claim to the contrary ${ }^{7}$. In that event, Callie's biological mother would be awarded custody. Callie, who had thus far lived as Rebecca, the presumptive granddaughter of her current caregivers, would be forced to live with a stranger. A preference-based approach, in sharp contrast, looks to the child. Assuming she is capable of stating her preference, she would choose her guardian and may even, were she capable of doing so, choose to live on her own.

Let us put this matter in other words. If the child is too young to choose, then the biological parents get the private property rights nod vis a vis the "mere" caregivers. Why? For two reasons: First, a genetic relationship is a more direct version of "homesteading" than is bringing up the baby. The mother and father have a greater connection to their offspring than someone who, due to this accident, brought up their child. Second, the fact of birth preceded, in time, what came later. Other things being equal, which they are not in this case, that alone would move us strongly in the direction of awarding the child to her natural parents. Given the first point, genetic connection, these two considerations together align justice on the side of biology. Let us consider the concept of adverse possession here. This is the rule under which if A occupies B's property, treating it as his own, and B does not object, after a sufficient length of time the property belongs to A. One can think of it as abandoned property again available to be homesteaded. This works reasonably well, perhaps, with a coat accidentally switched at a large party, or with a piece of land. It would appear to function less adequately with regard to children, if for no other reason than that they bear the genetic codes of their biological, not adoptive, parents.

At what age is the child old enough to choose? There is no right answer to this question. Libertarian theory alone cannot vouchsafe us a clear response. There is a continuum problem here, one that no political philosophy, including libertarianism, can unambiguously answer ${ }^{8}$. Whatever age is arbitrarily chosen,

7. That is, parents have a better claim to the child than any outsiders, because of their natural link to the child (14).

8. Given that statutory rape laws are justified, a position we now assume arguendo, what is the correct age at which they kick in? Clearly, going to bed with a five year old girl falls within the law, no matter how "willing" is the child. It is clear she has not yet reached, nor even come close, to the age of consent. And, of course, there will be youngsters below that age who are more mature than their contemporaries above that age. The only definitive answer emanating from this quarter is that the courts should decide this issue?.

\section{A brief history of children's rights}

The degree of freedom implied by libertarian theory, such as children's freedom to choose their guardians or, in the alternative, emancipation, differs markedly from the contemporary view of children's rights. But it comports with an older, widely held view of this issue. Other cultures and polities, ancient and modern, have granted children freedoms not permissible even for adults in much of Europe and the United States. The view that children require constant monitoring on the part of parents, guardians and the state, particularly governmental schools, is a relatively recent phenomenon (21).

In the Middle Ages, children, when no longer toddlers, were taken to be miniature adults. They routinely participated in adult activities (22). This attitude continued into the Renaissance, along with the widespread voluntary transfer of caregiver rights from unfit mothers to churches but also, unfortunately, the lack of economic wealth drove many mothers who could not afford their babies to commit infanticide (23).

During the European Renaissance, the practice arose of transferring to the Church and to lay caregivers children whose parents were thought to be unfit, and this alleged unfitness was frequently the consequence of an impoverishment that spurred the practice of infanticide. The onset of the Enlightenment, in line with developing theories of pedagogy further eroded this older concept of children as autonomous beings (which was the view of the medieval church). Yet, in contrast to this Enlightenment view, the prevailing attitude regarding children in pre-industrial America, was more akin to an older, medieval concept of children, and this was because of the economic conditions of most Americans, at that time, conditions that required, among other things, child labor.

The view of children as free individuals began to change during the Enlightenment when adults began philosophizing about the differences between adulthood and childhood in line with developing theories of pedagogy. Children continued to hold onto their freedom into the industrial revolution, but such freedom was not the result of a more just society. It was an unavoidable consequence of the pre-developed America with little wealth that children had to act grown up by working and living like adults.

In contrast to prevailing American attitudes toward children, the Wintu people of Northern California more thoroughly honor the freedom/rights of children. For example, in English, if you "take a baby" somewhere, there is an implicit sense of coercion. The Wintu language puts if differently: "I went with the baby". "I watched the child" would be, "I watched with the

\footnotetext{
having intercourse with a willing 25 year old woman cannot be considered rape But what about 15? 16? 14? There is no clear right answer. This is a matter for the courts to determine. For more on the continuum problem, see (15). It might well be objected that "this is a matter for the courts to determine" is not really an answer. On what basis are the courts to decide? Our response to this objection is that this is precisely why all civilized peoples have courts in the first place. Not every issue, most of them but not every one of them, can be resolved by resort to basic premises such as the NAP of libertarianism.
}

9. For the argument that these should be private, not governmental courts, see (3,16-20) 
child". The Wintu lack the word for coercion and even the concept of it. This, of course, does not mean they cannot engage in such acts, but, it makes it less likely. Of course, observation of actual practice would be far more relevant than mere linguistic analysis.

When a Wintu child asks, "May I...?" he is not asking for permission so much as for clarification about whether or not the proposed action comports with community norms. In that way, the child feels less at the mercy of a lone adult whose standards may seem capricious and arbitrary (24). Griffiths tells of tribes in which "five-year-olds wield[ing] machetes with deftness and precision", and in one instance, of an eight-year-old Igloolik ${ }^{10}$ child who carved the body of a caribou without mishap and of children in West Papua who set their own daily schedules, eating, sleeping, and playing as the spirit moves them ${ }^{11}$.

\section{Objections ${ }^{12}$}

1. Above, we say the following: "But surely the mother or parents may not receive the ownership of the child in absolute fee simple, because that would imply the bizarre state of affairs that a fifty-year old adult would be subject to the absolute and unquestioned jurisdiction of his seventy-year-old parent". The objection here is that this was in fact the legal situation under Roman law. Our only response, then, is that this system was truly bizarre. Parents would be able to literally enslave their children without the consent of the latter. This flies in the face of pretty much anything that most people hold sacred and properly so ${ }^{13}$. 2. Here is another challenge, which also starts off with a quote from what appears above:

"A court must pronounce judgment that this is indeed in the best interests of the tiny tot. Time must be used for sober analysis of the situation. Experts (social-workers, psychologists) must be brought in to verify the facts of the case. Then and only then may this 'absolute right to run away and to find new foster parents' be fully implemented".

The objection is that we are contradicting ourselves. On the one hand, we point out that a "time out" also requires the use of violence, not only spanking. But it is more than unusual to allow some people to coerce others until an authority rules that this is unjustified.

In responding to the "no spanking, but a time out is all right" argument, we pointed out its inconsistency in implying that parents cannot spank their children also implies that they cannot imprison them. A similar problem seems to arise here. We do not normally argue that individuals can coerce others until some authority rules that the coercion is not in the best interests of the victim. Justifying that claim requires something more than bare assertion".

Correct, this is not normally argued. But children are different than adults. They are not (yet) full rights bearing entities. If we leave an adult to his own devices, he is presumably able to run his own life, at least to his own satisfaction. But if a child is not cared for, for example, a three-year old, he must perish, since he cannot (yet) care for himself. Paternalism is not justified for adults, but it is for such youngsters. Libertarian theory is often at odds with mainstream legal philosophy but not so much, if

10. Igloolik is an Inuit Hamlet in Northern Canada.

11. The determination of whether or not these claims are actually true is beyond the expertise of the present authors.

12. We thank a referee of this journal for articulating these objections

13. But is it not true that the child consists, literally, of nothing he may properly call his own? His body is based, solely, on an egg, a sperm, neither of which belong to him but rather to his parents, plus nutrients, also given to him by them. He consists of nothing else but that which belongs to his parents. For an intriguing rejection of this plausible-seeming but actually preposterous claim, see (14). at all, with regard to acknowledging the fact that children are helpless, and incorporating this into the law.

Suppose an adult, call him A, is seen doing or refraining from doing something mildly injurious to his health. He eats food off the floor; he fails to brush his teeth; he eats unhealthily; he gets drunk (but does not drive a car); he does not clean his room, etc. Were another adult, call him B, to compel A to engage in better behavior in any of these regards, clearly, A's right will have been compromised by B. But now posit that $\mathrm{A}$ is a child of three years of age. His parents forbid/compel him to behave more properly in the same manner. It is our contention that the words "coerce" and "coercion" do apply to A the adult, but not at all to A the child, given that their behavior is identical. Now consider a second case where the parents beat the child to within an inch of his life. "Coerce" and "coercion" certainly now apply in this clear case of child abuse. But here it is no longer true that "individuals can coerce others until some authority rules that the coercion is not in the best interests of the victim". Rather, the child may be removed immediately from these criminal parents.

3. The next objection is as follows: This hard line libertarian position totally ignores parental obligations. Are the parents legally free to preside over the death of their child? Are they obliged to find an alternative caregiver if they no longer wish to be guardians? And what about costs, if the parents do not wish to raise $\mathrm{it}^{14}$.

Here is our answer to these challenges, according to what we see as libertarian theory ${ }^{15}$. But first some necessary background. No adult may properly own another without the latter's consent ${ }^{16}$. Human beings commit no wrong when they render into private property animate resources (cows) or inanimate ones (land, trees). Children occupy a middle ground between these two extremes. Parents may not own their progeny, but they are licitly in receipt of the guardianship rights over them, due to the fact that they have homesteaded them. They make keep these rights provided they live up to the requirements of guardianship: to guard the child against harm, to care for and feed him, educate him, etc. As there are no positive obligations, there is no requirement that the parent continue in this homesteading role. He may, instead, give the child up for adoption or sell it, or bring the unwanted baby to the traditional places: hospital, religious organization or orphanage. But is this latter requirement not a violation of the no positive obligations rule? Not at all. For if a parent who no longer wishes to care for a child simply allows him to starve to death without notifying anyone that he wishes to rid himself of this relationship, he commits the rights violation of illicit precluding or forestalling ${ }^{17}$. What is that? Consider a patch of land shaped like a donut with a hole in the middle of it. $\mathrm{A}$ is the hole, $\mathrm{B}$ is the donut, $\mathrm{C}$ is the area outside of the donut. Is the homesteader allowed by libertarian theory to mix his labor with area $\mathrm{B}$, and not allow anyone from area $\mathrm{C}$ access to area A? No. Because then he would have obtained effective control over area $\mathrm{A}^{18}$ without having touched it. He would, in effect, own it in the sense that he could preclude all other from access, and then homestead it at his leisure. The parent who starves a baby without notifying anyone of this breach of guardianship is akin to the person who homesteads B's land. Only here, the baby takes on the role of A. Such a parent is violating the rights of the baby and of all others who might wish to care for him by precluding access of the latter to the former.

\footnotetext{
14. Bill Bradford, Editor of Liberty Magazine, raised these issues in his polls of libertarian beliefs in the magazine; see on this (25-28).

15. For a further elaboration, see (3,29-31).

16. For a defense of voluntary slavery, the discussion of which would take us too far away from the topic of this paper, see (32-34).

17. For a further elaboration of this concept, see $(11,35-37)$

18. He can prevent others from entry.
} 
With this background, let us now respond to the challenges to the theory posed above.

Do the parents have any obligation to support the child? No. Are they free to dump him out? Yes, to the orphanage, hospital, religious organization that takes on babies or to an adoptive parent. May the initial parent starve or freeze the baby to death? Certainly not. Are the parents obliged to try to find an alternative caregiver first? Yes, indeed. However, if there is not a single solitary adult on the planet who wishes to take on this role, then and only then may the baby be put to death. Can the parents, for instance, put the child behind a window and charge viewers to watch it starve to death? No; that is grotesque. Do they have an obligation to find alternative caregivers? Yes; this does not constitute a positive obligation based on forestalling theory. Must they, by law, give notice that the child is in need of a caregiver? Yes. Must they bear any costs at all to keep the child from dying, supposing they do not want to raise it? The only costs they need bear are those necessary to bring the child to the proverbial church steps or make other similar arrangements.

\section{Conclusion}

Rothbard's theory of the natural rights of children, though radical in the contemporary American context, is normative in the context of more traditional cultures. The framework he laid out was an important step in articulating rights to one of the last minorities in the United States to obtain legal and political rights, minors. The crucial issue Rothbard raises is the weight to be given to a child's preferences in the matter of strict/ mandatory vs. permissive/optional caregiving.

\section{Acknowledgments}

The authors owe a debt of gratitude to Michael Makovi for inspiring the writing of this article. We are also greatly indebted to a referee of this journal for posing a series of objections to our thesis, and inviting us to reply to them. The usual caveats, of course, apply.

Ethical issues

Not applicable.

\section{Competing interests}

The authors declare that they have no competing interests.

\section{Authors' contributions}

All three authors played an equal role in writing and further revising and editing this paper.

\section{Authors' affiliations}

'Joseph A. Butt, S.J. College of Business, Loyola University, New Orleans, USA. 2120 Pulpit Hill Road, Amherst, USA. ${ }^{3}$ Joseph A. Butt, S.J. College of Business, Loyola University, New Orleans, USA.

\section{References}

1. Rothbard MN. For a New Liberty. New York: Macmillan; 1973.

2. Huebert J. Libertarianism Today. Santa Barbara, CA: Praeger; 2010.

3. Rothbard MN. Children and Rights. In: Rothbard MN, editor. The Ethics of Liberty. New York: New York University Press; 1998.

4. Gopnik A. How Babies Think. Sci Am 2010; 303: 76-81.

5. Molyneux S. Spanking, Aggression and Ethics [internet]. Available from: http://www.youtube.com/watch?v=es2d2c-YXeY

6. Molyneux S. Does Spanking Violate the Non-Aggression Principle? [internet]. 2012 July 21. Available from: http://board. freedomainradio.com/topic/33222-does-spanking-violate-the-nonaggression-principle/

7. Szasz TS. Law, liberty, and psychiatry; an inquiry into the social uses of mental health practices. New York: Macmillan; 1963

8. Szasz TS. The Lying Truths of Psychiatry. J Libert Stud 1979; 3: 121-39.

9. Baillargeon R, Spelke ES, Wasserman S. Object permanence in 5-month-old infants. Cognition 1985; 20: 191-208.

10. Repacholi BM, Gopnik A. Early reasoning about desires: Evidence from 14- and 18-month-olds. Dev Psychol 1997; 33: 12-21.

11. Block WE. Terri Schiavo: A Libertarian Analysis. J Libert Stud 2011; 22: 527-36.

12. Stout D. Judge Denies Custody to Mother of Switched Baby [internet]. 1999 November 13. Available from: http://www.nytimes. com/1999/11/13/us/judge-denies-custody-to-mother-of-switchedbaby.html

13. National News Briefs. Mother to Seek Custody Of Girls Switched at Birth [internet]. 1999 April 7. Available from: http://www.nytimes. com/1999/04/07/us/national-news-briefs-mother-to-seek-custodyof-girls-switched-at-birth.html

14. Kinsella S. How We Come to Own Ourselves [internet]. 2006 September 7. Available from: http://mises.org/daily/2291

15. Block WE, William BI. Continuums. Journal Etica e Politica/Ethics \& Politics 2008; 1: 151-66.

16. Benson BL. The Enterprise of Law: Justice Without the State. San Francisco: Pacific Research Institute for Public Policy; 1990.

17. Hoppe H. Democracy - The God That Failed. Rutgers University, N.J.: Transaction Publishers; 2001.

18. Rothbard MN. Free Market, Police, Courts, and Law. Reason 1973; 5-19.

19. Rothbard M. On Denationalizing the Courts, Rothbard-Rockwell Report. Burlingame, CA: Center for Libertarian Studies; 1991.

20. Stringham E. Justice Without Government. J Libert Stud 1998; 14 53-77.

21. Liggio LP, Peden JR. Social scientists, schooling and the acculturation of immigrants in 19th century America. J Libert Stud 1978; 2: 69-84.

22. Madoc-Jones B, Coates J. An introduction to women's studies. Hoboken, NJ: Wiley-Blackwell; 1996.

23. King M. The Renaissance in Europe. London: Laurence King Publishing; 2003.

24. Griffiths J. The Riddle Of The Childscape. Penguin Books; 2013.

25. Bradford B. The Liberty Poll: Who We Are and What We Think. Liberty magazine 1998; 1: 37-48.

26. Bradford B. The Liberty Poll: What libertarians believe is often at odds with libertarian orthodoxy. And their beliefs are changing in some surprising ways. Liberty magazine 1999; 13: 11-21.

27. Rand M. The Liberty Poll Results; Who We Are and What We Think. Liberty magazine 2008; 22: 29-43.

28. Zwolinski M. What Do Libertarians Believe About the NonAggression Principle? [internet]. 2013 May 7. Available from: http://www.libertarianism.org/blog/what-do-libertarians-believeabout-non-aggression-principle

29. Block WE. Defending the Undefendable. Auburn, AL: The Mises Institute; 2008 [1976].

30. Block WE. Libertarianism vs. Objectivism; A Response to Peter Schwartz. Reason Papers 2013; 26: 39-62.

31. Block WE, Fleischer M. How Would An Anarchist Society Handle Child Abuse? [internet]. 2010 October 13. Available from: http:// www.lewrockwell.com/block/block167.html

32. Block WE. Toward a Libertarian Theory of Inalienability: A Critique of Rothbard, Barnett, Gordon, Smith, Kinsella and Epstein. J Libert Stud 2003; 17: 39-85 .

33. Nozick R. Anarchy, State and Utopia. New York: Basic Books; 1974.

34. Philmore J. The libertarian case for slavery. Philos Forum 1984; 14: 43-58.

35. Block WE. Libertarianism, Positive Obligations and Property Abandonment: Children's Rights. Int J Soc Econ 2004; 31: 275-86.

36. Block WE. Homesteading, ad coelum, owning views and forestalling. The Social Sciences 2008; 3: 96-103.

37. Block WE. Toward a libertarian theory of evictionism. J Fam Econ Issues 2013 June. doi: 10.1007/s10834-013-9361-4 